\title{
Leukocyte gene expression in post-thrombotic syndrome
}

Citation for published version (APA):

Iding, A. F. J., Witten, A., Isaacs, A., Castoldi, E., ten Cate, H., Stoll, M., \& ten Cate-Hoek, A. J. (2021). Leukocyte gene expression in post-thrombotic syndrome. Thrombosis Research, 202, 40-42. https://doi.org/10.1016/j.thromres.2021.03.007

Document status and date:

Published: 01/06/2021

DOI:

10.1016/j.thromres.2021.03.007

Document Version:

Publisher's PDF, also known as Version of record

Document license:

Taverne

Please check the document version of this publication:

- A submitted manuscript is the version of the article upon submission and before peer-review. There can be important differences between the submitted version and the official published version of record.

People interested in the research are advised to contact the author for the final version of the publication, or visit the DOI to the publisher's website.

- The final author version and the galley proof are versions of the publication after peer review.

- The final published version features the final layout of the paper including the volume, issue and page numbers.

Link to publication

\footnotetext{
General rights rights.

- You may freely distribute the URL identifying the publication in the public portal. please follow below link for the End User Agreement:

www.umlib.nl/taverne-license

Take down policy

If you believe that this document breaches copyright please contact us at:

repository@maastrichtuniversity.nl

providing details and we will investigate your claim.
}

Copyright and moral rights for the publications made accessible in the public portal are retained by the authors and/or other copyright owners and it is a condition of accessing publications that users recognise and abide by the legal requirements associated with these

- Users may download and print one copy of any publication from the public portal for the purpose of private study or research.

- You may not further distribute the material or use it for any profit-making activity or commercial gain

If the publication is distributed under the terms of Article $25 \mathrm{fa}$ of the Dutch Copyright Act, indicated by the "Taverne" license above, 
Letter to the Editors-in-Chief

Leukocyte gene expression in post-thrombotic syndrome
A R T I C L E I N F O

\section{Keywords}

Venous thrombosis

Post-thrombotic syndrome

Leukocytes function/activation

Case-control study

Transcriptomics

Post-thrombotic syndrome (PTS) is the most common long-term complication of deep vein thrombosis (DVT), with an incidence of one in three patients [1]. It has a significant impact on quality of life and is associated with considerable societal costs [1]. The onset of PTS is understood to be a consequence of hampered DVT recanalization, which is a combination of fibrinolyisis, thrombus reorganization and neovascularization [1]. This process is guided by leukocytes, which infiltrate the thrombus and vein wall [1]. Pro-inflammatory leukocyte activity can slow thrombus resolution and damage the vein wall, causing venous outflow restriction and valvular reflux [1]. The ensuing venous hypertension is transmitted to the microcirculation, where leukocytes adhere and migrate across the endothelium under low shear stress [1]. The resultant perivascular inflammation leads to the characteristic manifestations of PTS, including pain, edema and skin changes of the leg [1].

Despite the paramount role of leukocytes in the onset of PTS, clinical studies have largely been limited to measurement of circulating inflammatory markers. Meanwhile, the actual activity of leukocytes is reflected by their transcriptome, which is the collection of all RNA species expressed by a particular cell type at a particular point in time. We hypothesized that the leukocyte transcriptome of patients with PTS is different from patients who did not develop PTS after DVT.

In a previously conducted case-control study, we recruited 30 patients with PTS (cases) and 30 patients with a history of DVT without PTS (controls). The study design and patient characteristics are described in a previous publication [2]. In brief, patients were selected from a cohort that was followed prospectively after acute DVT. PTS was defined as a Villalta score, the recommended diagnostic tool, of $\geq 5$ on two consecutive visits with at least 3 months in between [1]. The study was approved by the medical ethical committee and all patients gave written informed consent. Patient characteristics were analyzed in SPSS 26.0 (SPSS Inc., Chicago, IL, USA). Continuous variables were compared between the patient groups with non-parametric Mann-Whitney $U$ tests, and were considered significant at $p \leq 0.05$. These variables were presented as medians with interquartile ranges. Fisher's Exact test was used to compare categorical variables between groups.

The patients' buffy coat was obtained by centrifugation of venous blood, mixed with an RNA stabilization reagent, and stored at $-20{ }^{\circ} \mathrm{C}$ [2]. For the current study, total RNA was isolated from these preserved buffy coats, including a DNase digestion step. RNA quality was assessed by measuring concentration, purity and RNA Integrity Number (RIN), using the Bioanalyzer RNA 6000 Nano or Pico Kit (Agilent Technologies, Palo Alto, CA, USA). After enrichment for Poly(A) RNA with the NEBNext Poly(A) mRNA Magnetic Isolation Module (New England Biolabs, Ipswich, MA, USA), the RNA was fragmented and complementary DNA was synthesized directionally with random primers. The double stranded complementary DNA fragments were flanked with specific adapters, and each library was tagged with a molecular barcode for multiplex downstream analysis using the NEBNext Ultra II Directional RNA Library Prep Kit for Illumina (New England Biolabs, Ipswich, MA, USA). Library quality was assessed with the TapeStation 4200 using D1000 ScreenTape (Agilent Technologies, Palo Alto, CA, USA), and libraries were quantified using the NEBNext Library Quant kit for Illumina (New England Biolabs, Ipswich, MA, USA). Libraries were pooled in equimolar proportions and directionally sequenced on the NextSeq500 system with the SBS chemistry kit v2.5 (Illumina Inc., San Diego, CA, USA) at high-output mode for 75 cycles to gain a sufficient number of reads per sample.

Differentially expressed genes (DEGs) between patient groups were determined according to a common data analysis pipeline in the $\mathrm{R}$ base package [3]. This included an assessment of sequence quality with FastQC, computation of counts with HTSeq, and differential expression analysis with DESeq2. DEGs needed to be well expressed, defined as $\geq 10$ counts in at least $90 \%$ of the samples. Differences between groups were expressed as fold changes (FC). DEGs were considered significant at a false discovery rate (FDR) adjusted $p$-value $\leq 0.10$. Principal component analysis and enrichment analysis were performed with the top 50 DEGs ranked by FDR adjusted p-value.

Assessment of RNA quality revealed a low overall concentration (mean: $17.4 \mathrm{ng} / \mu \mathrm{L}$ ), purity (mean 260/280 nm: 1.56) and RIN (mean: 5.4). It was thus decided to select only patients with the highest RNA quality at a RIN $>5$ for sequencing. Samples from 6 cases and 7 controls were selected, having an acceptable concentration (mean: $11.4 \mathrm{ng} / \mu \mathrm{L}$ ), purity (mean 260/280 nm: 1.72) and RIN (mean: 6.5). Baseline characteristics were comparable between groups (Table 1), except for a significantly higher BMI in cases. Naturally, the Villalta score in cases was higher than in controls. Cases had mostly mild PTS, which is defined as a Villalta score below 10 . 
Table 1

Characteristics of selected patients.

\begin{tabular}{|c|c|c|c|}
\hline & Cases $(n=6)$ & Controls $(n=7)$ & P-value \\
\hline Age, median (IQR) & $66(55-73)$ & $71(56-80)$ & 0.445 \\
\hline Male sex (\%) & $3(50 \%)$ & $1(14 \%)$ & 0.266 \\
\hline BMI, median (IQR) & $32(28.9-33.9)$ & $24.6(23.3-32.0)$ & 0.035 \\
\hline Villalta score, median (IQR) & $6.75(5.5-12.2)$ & $2.33(2.0-3.0)$ & 0.001 \\
\hline Recurrent DVT (\%) & $4(67 \%)$ & $4(57 \%)$ & 1.000 \\
\hline Follow-up after first DVT, median months (IQR) & $57.5(33.5-83.0)$ & $60(21-144)$ & 1.000 \\
\hline Follow-up after most recent DVT, median months (IQR) & $42(7.5-62.75)$ & $60(40-75)$ & 0.234 \\
\hline Oral anticoagulant use (\%) & $3(50 \%)$ & $2(29 \%)$ & 0.592 \\
\hline Statin use (\%) & $2(33 \%)$ & $3(43 \%)$ & 1.000 \\
\hline
\end{tabular}

Abbreviations: IQR, interquartile range; BMI, body mass index; DVT, deep vein thrombosis.

Sequencing yielded about 30 million single reads for each sample, corresponding with nearly 64,000 unique transcripts of which 26,000 were well expressed. Principal component analysis revealed reasonable separation of patient groups on the first principal component, which explained $25 \%$ of variance. The top 50 DEGs all had an FDR adjusted $p$ value $<0.30$, and enrichment analysis revealed an overrepresentation of ribosomal pathways. Twelve DEGs were significantly different, which were HDGFL3 (FC = 1.52), ADIPOR1 $(\mathrm{FC}=0.29)$, PPIA $(\mathrm{FC}=0.40)$, $R P L 12(\mathrm{FC}=0.60), R P 13 A(\mathrm{FC}=0.64), R P S 14(\mathrm{FC}=0.64), R P L 41(\mathrm{FC}$ $=0.51)$, KCNQ1OT1 $(\mathrm{FC}=1.89)$, AC011462.2 $(\mathrm{FC}=1.75)$, AC092384.2 $(\mathrm{FC}=1.90), A F 127577.1(\mathrm{FC}=0.61)$, and $A L 596202.1(\mathrm{FC}=2.96)$. The FDR adjusted $p$-value was 0.02 for HDGFL3, and 0.09 for all other DEGs.

The twelve significant DEGs included five long non-coding RNAs (KCNQ1OT1, AC011462.2, AC092384.2, AF127577.1, AL596202.1) of which the cellular effect in leukocytes is unknown. Another four downregulated DEGs (RPL12, RP13A, RPS14, RPL41) coded for ribosomal proteins. Downregulation of ribosomal proteins has previously been observed in leukocytes as part of an inflammatory response [4]. The remaining three DEGs were considered to have pathologic potential due to the effects of their protein products. The increased expression of HDGFL3 indicates an upregulation of its product, the potent angiogenic factor hepatoma-derived growth factor-related protein-3 (HDGFRP3) [5]. Indeed, angiogenic factors are known to be essential in thrombus resolution by stimulating neovascularization (Fig. 1A) [1]. The decreased expression of ADIPOR 1 suggests downregulation of the adiponectin receptor 1. Its ligand, adiponectin, is an anti-inflammatory and anti-fibrotic hormone which is not only systemically released by adipocytes, but also locally by the endothelium (Fig. 1B) [6]. In a recent cohort study, low adiponectin levels at three months after DVT were shown to predict the onset of PTS. [7] Finally, there was a decreased expression of the gene PPIA, which codes for cyclophilin A. Besides an intracellular role in protein trafficking, this protein is also secreted by leukocytes in response to inflammatory stimuli. It has chemotactic effects and is thought to have an important role in inflammation and vascular remodeling (Fig. 1C) [8].

Limitations of our study are the lack of technical validation and the significantly higher BMI in cases. However, RNA sequencing data is often considered to be reliable in itself, since DESeq2 normalization corrects for all gene expression. In respect to the difference in BMI, it is promising that the predictive value of adiponectin was shown to be independent of BMI [7]. Nevertheless, additional research is needed to confirm our findings.

In conclusion, our study found differences between the leukocyte transcriptomes of patients with and without the onset of PTS after DVT. This was found despite our cases having mostly mild PTS. The results suggest an underlying inflammatory state in PTS, which is in accordance with other studies on circulating inflammatory markers [9]. We identified candidate markers of inflammation and angiogenesis which have not been previously associated with PTS. Once confirmed in larger casecontrol studies, our results could provide further pathologic insight and might even lead to much-needed therapeutic targets in the prevention and treatment of PTS. To the best of our knowledge, this is the first transcriptomics study in the field of PTS. We hope that these findings will encourage the utilization of this bottom-up approach to advance knowledge in the field of PTS.
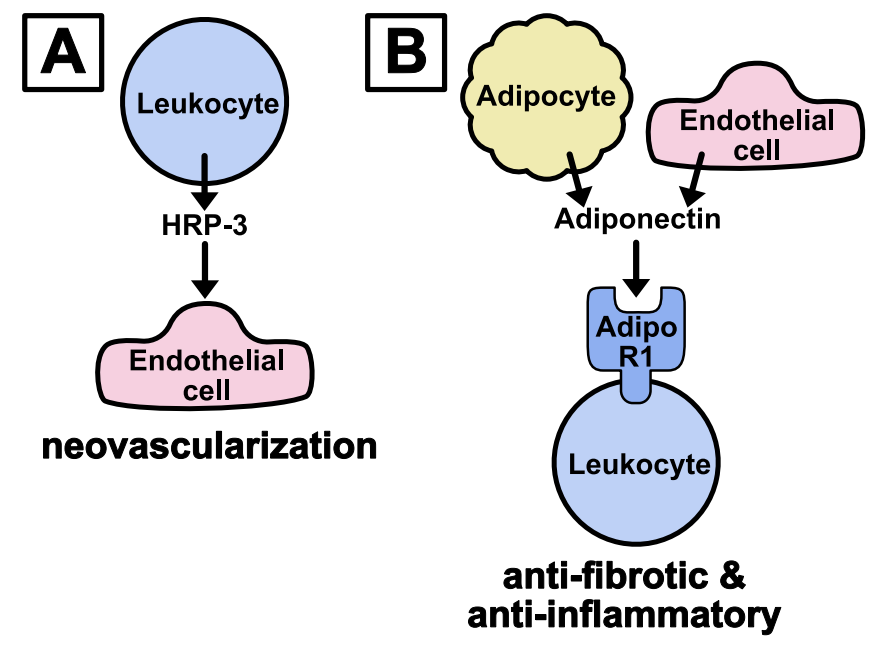

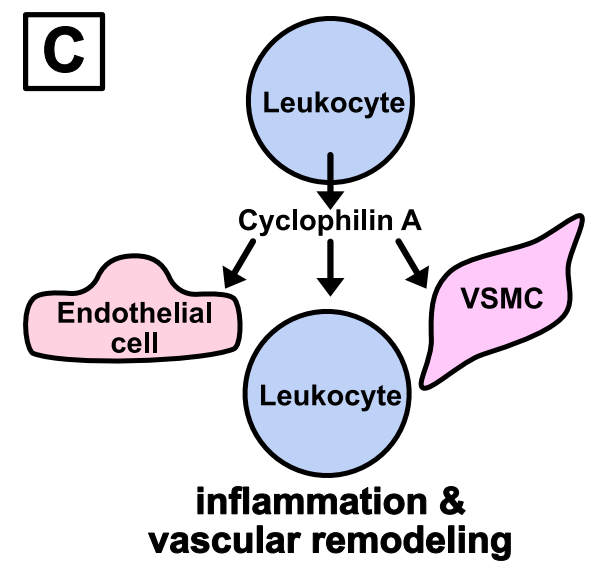

vascular remodeling

Fig. 1. DEGs with pathophysiologic potential.

Abbreviations: HRP-3, hepatoma-derived growth factor-related protein-3; AdipoR1, adiponectin receptor 1; VSMC, vascular smooth muscle cell. 


\section{Authors' contributions}

AFJI and AW performed the laboratory analyses; MS and EC supervised the laboratory analyses; AI performed the data analysis; AtC, MS and $\mathrm{HtC}$ conceived the study concept; AtC contributed to the study design, funding, recruitment of patients, data collection and data interpretation; AFJI wrote the manuscript; AtC supervised the writing; all other authors contributed equally to the review of the manuscript and approved the final manuscript.

\section{Declaration of competing interest}

The authors declare that they have no known competing financial interests or personal relationships that could have appeared to influence the work reported in this paper.

\section{References}

[1] A.J. ten Cate-Hoek, P.K. Henke, T.W. Wakefield, The post thrombotic syndrome: ignore it and it will come back to bite you, Blood Rev. 30 (2) (2016) 131-137, https://doi.org/10.1016/j.blre.2015.09.002.

[2] Y.W. Cheung, A.C. Bouman, E. Castoldi, et al., Toll-like receptor 9 gene expression in the post-thrombotic syndrome, residual thrombosis and recurrent deep venous thrombosis: a case-control study, Thromb. Res. 140 (2016) 106-109, https://doi. org/10.1016/j.thromres.2016.02.025.

[3] R Development Core Team, R: A Language and Environment for Statistical Computing [Computer Program], R Foundation for Statistical Computing, Vienna, Austria, 2008.

[4] H.N. Khan, D. Perlee, L. Schoenmaker, et al., Leukocyte transcriptional signatures dependent on LPS dosage in human endotoxemia, J. Leukoc. Biol. 106 (5) (2019) 1153-1160, https://doi.org/10.1002/JLB.4A0219-050R.
[5] M.E. LeBlanc, W. Wang, N.B. Caberoy, et al., Hepatoma-derived growth factorrelated protein-3 is a novel angiogenic factor, PLoS One 10 (5) (2015), e0127904, https://doi.org/10.1371/journal.pone.0127904.

[6] Y. Luo, M. Liu, Adiponectin: a versatile player of innate immunity, J. Mol. Cell Biol. 8 (2) (2016) 120-128, https://doi.org/10.1093/jmcb/mjw012.

[7] S. Mrozinska, J. Cieslik, E. Broniatowska, A. Undas, Elevated leptin and decreased adiponectin independently predict the post-thrombotic syndrome in obese and nonobese patients, Sci. Rep. 8 (1) (2018) 6938, https://doi.org/10.1038/s41598-01825135-y.

[8] P. Nigro, G. Pompilio, M.C. Capogrossi, Cyclophilin A: a key player for human disease, Cell Death Dis. 4 (2013), e888, https://doi.org/10.1038/cddis.2013.410.

[9] A.C. Bouman, S. Atalay, H. Ten Cate, M. Ten Wolde, A.J. Ten Cate-Hoek, Biomarkers for post-thrombotic syndrome, J. Vasc. Surg. Venous Lymphat. Disord. 2 (1) (2014) 79-88.e73, https://doi.org/10.1016/j.thromres.2014.06.010.

Aaron F.J. Iding ${ }^{\mathrm{a}, \mathrm{b}, *}$, Anika Witten ${ }^{\mathrm{c}}$, Aaron Isaacs ${ }^{\mathrm{d}}$, Elisabetta Castoldi ${ }^{\mathrm{b}}$, Hugo ten Cate ${ }^{\mathrm{a}, \mathrm{b}, \mathrm{e}}$, Monika Stoll ${ }^{\mathrm{b}, \mathrm{c}}$, Arina J. ten Cate-Hoek ${ }^{\mathrm{a}, \mathrm{b}}$

a Thrombosis Expertise Center, Heart+Vascular Center, Maastricht University Medical Center (MUMC), Maastricht, the Netherlands

${ }^{\mathrm{b}}$ Department of Biochemistry, Cardiovascular Research Institute Maastricht (CARIM), Maastricht University, Maastricht, the Netherlands

${ }^{\mathrm{c}}$ Department of Genetic Epidemiology, Institute of Human Genetics, University Hospital Münster, Münster, Germany

${ }^{\mathrm{d}}$ Department of Physiology, CARIM, Maastricht University, Maastricht, the Netherlands

e Department of Internal Medicine, MUMC, Maastricht, the Netherlands

* Corresponding author at: Joseph Bechlaan 113, 6229 GR Maastricht, the Netherlands. E-mail address: a.iding@maastrichtuniversity.nl (A.F.J. Iding). 